\title{
終末糖化産物によるサイトカイン捕捉機構の同定と病態生理学的意義の解明
}

\author{
渡邊 政博
}

\section{Towards Understanding the Pathophysiological Significance of Cytokine Trapping Mediated by Advanced Glycation End Products}

\author{
Masahiro Watanabe \\ Department of Pharmacology, School of Pharmacy, Shujitsu University; \\ 1-6-1 Nishigawara, Naka-ku, Okayama 703-8516, Japan.
}

(Received June 23, 2020)

\begin{abstract}
Advanced glycation end products (AGEs) are non-enzymatically formed from sugars or their metabolites with biomolecules. These molecules are formed in vivo, and the formation of AGEs on functional biomolecules was demonstrated to alter their properties. In addition, AGEs were reported to elicit inflammatory reactions by stimulating their endogenous receptors. However, the relationship between AGEs and these phenomena remains unclear. To understand the pathophysiological roles of AGEs, we investigated their action mechanisms at the molecular level. In this study, we found that AGEs can directly interact with tumor necrosis factor-like weak inducer of apoptosis (TWEAK), the cytokine that controls tumor necrosis factor- $\alpha(\mathrm{TNF}-\alpha)$-stimulated inflammatory reactions. This interaction inhibited the action of TWEAK and subsequently increased TNF- $\alpha$-induced proinflammatory cytokine expression. This raised the possibility that AGEs trap other cytokines and alter their activities. We named this hypothesis "AGE-mediated cytokine trapping". To assess this hypothesis, we next examined the mechanism of AGE-TWEAK interaction. The pull-down assay using the deletion mutant revealed that a relatively large region of TWEAK functions in the interaction with AGEs, suggesting that it is difficult to explore other cytokines capable of interacting with AGEs using TWEAK sequence similarity. Therefore, to find novel AGE-cytokine interactions, we performed comprehensive screening using a protein array and found several candidates. To generalize "AGE-mediated cytokine trapping", detailed studies using these candidates are now in progress.
\end{abstract}

Key words__ advanced glycation end product; cytokine; inflammation

\section{1. はじめに}

わが国は急激な老齢人口の増大局面を迎えてお り，健康寿命の延伸が喫緊の課題となっている。こ れを解決するためには，健康寿命に大きく影響する 糖尿病や脳・心血管疾患などの疾患が生じるメカニ ズムを解明し, 治療戦略を構築することが必要であ る.

これらの疾患の基盤として, 非感染性の炎症反応 の遷延化（慢性炎症）が注目されている．最近の研 究により, 複数の炎症性サイトカインが協調的に作 用することで生じた慢性炎症が, 細胞や組織の機能 不全を引き起こし, 慢性炎症性疾患が成立すること

就実大学薬学部生体情報学（下703-8516 岡山市中区西 川原 1-6-1)

e-mail: mwatana@shujitsu.ac.jp

本総説は, 2019 年度日本薬学会中国四国支部奨励賞の

受賞を記念して記述したものである.
が示唆されている.

このように，「どのようにして慢性炎症性疾患が 成立するのか」については解明が進みつつある。一 方で，「なぜ慢性炎症が生じるのか」が未解明であ るため, 慢性炎症性疾患の根治的な治療法の開発が 妨げられている.

筆者は，慢性炎症の引き金を引く分子の候補とし て，還元糖がアミノ基を有する分子と非酵素的に結 合することによって生じる終末糖化産物（advanced glycation end products; AGEs) に注目して いる. 従来 AGEs は, 食品の褐変現象の要因とし て認識されてきた．AGEs は，食品の見た目のみな らず，味の変化にも関与すると考えられており，主 に食品科学の領域において研究対象となってきた. その後, 近年になって AGEs が生体内において生 成していることが明らかとなつた。 ${ }^{1,2)}$ 糖尿病の診断 に用いられるへモグロビン Alc は，AGEs の一種 
である。ささら，特定の生体分子において AGEs が生成する（生体分子が AGEs 化される）ことに より，その分子の機能が変化する事例が報告され た。 こ)これらの現象は，生体内において生じた AGEs（化）が直接的に疾患の要因となり得ること を強く示唆している．AGEsは，酸化ストレスや高 血糖の持続により蓄積量が増大することが報告され

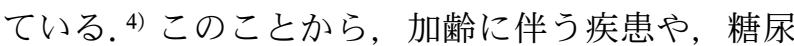
病・メタボリックシンドロームなどの病態形成に AGEs が寄与している可能性が考えられる。注目す べき点として，これらの疾患と，慢性炎症が背景に あることが示唆されている疾患が重複していること が挙げられる.

さらに最近になって AGEs は，受容体である receptor for AGEs (RAGE) を刺激することによ り，炎症反応を活性化することが示された。 5,6 この 知見は，加齢や生活習慣により生体内に蓄積した AGEs が，AGEs-RAGE 系の活性化を介して「慢 性」炎症をひきおこす可能性を示唆している。一方 で，受容体である RAGE の発現プロファイルは， 特定の組織や細胞に限局されている。ささに, AGEs が RAGE を刺激して炎症反応を促進するメ カニズムは，完全には明らかになっておらず，この 系を介した炎症が慢性化するメカニズムについても 同様に不明確である。これらのことから筆者は, AGEs が起点となる炎症反応の慢性化には，AGEsRAGE 系以外の未知のメカニズムが関与している 可能性があると考えている.

この可能性について検討することを目的として， 筆者は AGEs の作用メカニズムに焦点をあてた解 析を行ってきた。これまでに，AGEs と相互作用す る可能性を持つ内在性分子の探索を行い，複数の候 補分子を見い出した。 これらの候補分子の 1 つは, 炎症反応の制御に係わるサイトカインである tumor necrosis factor-like weak inducer of apoptosis （TWEAK）であった。AGEs との相互作用は， TWEAK による炎症反応の制御に影響を与える可 能性が考えられる。このような AGEs の作用はこ れまでに報告されておらず，この可能性を立証する ことは，AGEsが慢性炎症に関与する新規メカニズ ムの解明につながることが期待できる.

そこで本研究において筆者は，AGEs との相互作 用が TWEAK の機能に与える影響を解析し，内在
性分子との相互作用を介して AGEs が慢性炎症に 関与するメカニズムの立証を試みた.

\section{AGEs との相互作用が TWEAK の機能に与 える影響の解析}

サイトカインとしての TWEAK は，膜貫通タン パク質として発現した全長 TWEAK の C 未端側 （ヒト TWEAK の 97Lys-249His）が，タンパク質 切断酵素 Furin により切り出されることにより生成 する。そのため TWEAK は, 可溶性 TWEAK とも よばれる（本論文では可溶性 TWEAK を TWEAK と記載した)。細胞培養系を用いた解析により， TWEAK は非常に多彩な機能を有することが示唆

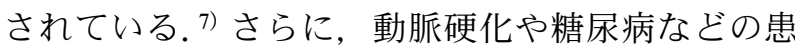
者において TWEAK の血中濃度が変化することが 報告されている. ${ }^{8-11)} こ れ ら の$ 知見は，TWEAK が 疾患の発症に関与している可能性を示唆している.

TWEAK は，代表的な炎症性サイトカインである tumor necrosis factor- $\alpha$ (TNF- $\alpha)$ よりも作用は弱い ものの血管内皮細胞モデルである EA.hy926 細胞を 刺激して interleukin-8 (IL-8) の発現を誘導する. そこで，この評価系に AGEs を共存させた場合の 影響を検討したところ，AGEs は TNF- $\alpha$ による IL-8 の発現誘導に影響しないのに対して，TWEAK による IL-8 の誘導を阻害することが見い出され た. ${ }^{12)} こ の$ 結果は, AGEs と TWEAK の相互作用が TWEAK の作用を変化させたことを示唆している と考えられた。

続いて，より生理的な条件下において AGETWEAK 相互作用の影響を検討した。TWEAK の 生理的な役割は，TNF- $\alpha$ による過㮃な炎症反応の 制御にある可能性が報告されている，既報に基づい て，筆者の評価系においてこの現象の再現を試みた ところ，TWEAK の共存下において培養した EA.hy926 細胞をTNF- $\alpha$ により刺激すると, TWEAK の共存培養がない場合と比較して IL-8の 発現誘導が抑制されることが確認された（Fig. 1). ${ }^{12)}$ この結果は，過去の報告と同様に，TWEAK が TNF- $\alpha$ による炎症の誘導を制御する作用を有す ることを示唆している。 そこで，この評価系におい て，TWEAK の作用に対する AGE-TWEAK 相互作 用の影響を検討した。 TWEAK と AGEs の共存下 において培養した細胞を用いた検討を行ったとこ ろ，先の検討結果と同様に，AGEs は TWEAK の 


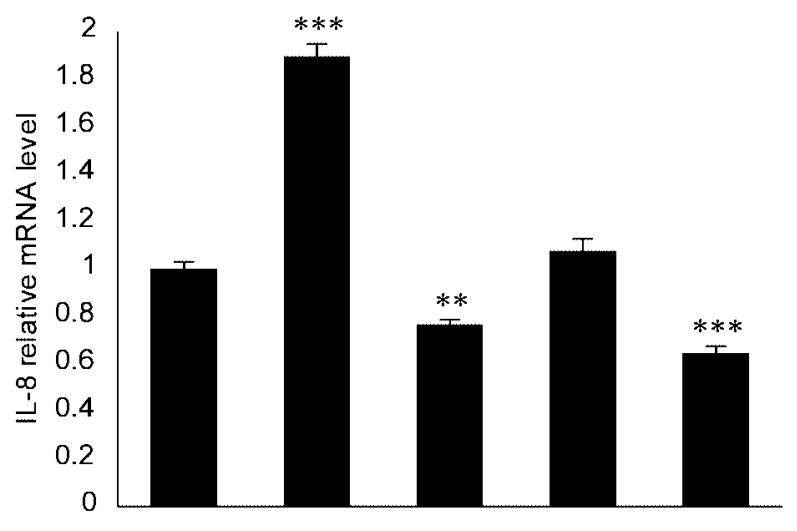

$\begin{array}{rrrrrr}\text { TNF- } \alpha & + & + & + & + & + \\ \text { TWEAK } & - & + & + & + & + \\ \text { AGEs } & - & - & - & + & - \\ \text { BSA } & - & - & - & - & + \\ \text { TWEAK pretreatment } & - & - & + & + & + \\ \text { AGEs pretreatment } & - & - & - & + & - \\ \text { BSA pretreatment } & - & - & - & - & +\end{array}$

Fig. 1. The Changes of TNF- $\alpha$-induced IL-8 Gene Expression in EA.hy926 Cells Pretreated with TWEAK together with or without AGEs

Initially, the cells were pretreated for $30 \mathrm{~h}$ with or without molecules as follows: TWEAK $(100 \mathrm{ng} / \mathrm{mL}) ; \mathrm{AGEs}(1000 \mu \mathrm{g} / \mathrm{mL}) ; \mathrm{BSA}(1000 \mu \mathrm{g} / \mathrm{mL})$. Then the cells were treated for $6 \mathrm{~h}$ with or without molecules as follows: TNF- $\alpha(50 \mathrm{ng} / \mathrm{mL}), \mathrm{TWEAK}(100 \mathrm{ng} / \mathrm{mL}), \mathrm{AGEs}(1000 \mu \mathrm{g} / \mathrm{mL}), \mathrm{BSA}(1000 \mu \mathrm{g} / \mathrm{mL}) . \mathrm{Data}$ are shown as ratios to the IL-8 gene expression level in the cells treated with TNF- $\alpha$ alone for $6 \mathrm{~h}$ as a control. ${ }^{* *} p<0.01$; ${ }^{* *} p<0.001$ versus control by Dunnett's test $(n=3)$. Reproduced from Mol. Cell. Biochem., 434(1-2), 153-162 (2017), with permission.

作用を阻害し，TNF- $\alpha$ による IL-8 の発現誘導の抑 制が生じ難くなることが示された（Fig. 1).12)

さらに，プルダウンアッセイにより AGEs と TWEAK, TNF- $\alpha$ 及び IL-8 の間の相互作用を検討 した。その結果, AGEs は TWEAK に加えて IL-8 とも相互作用することが示唆された（Fig. 2). ${ }^{12)}$ 一 方で AGEs は，TNF- $\alpha$ とは相互作用しないことが 示唆された (Fig. 2). ${ }^{12)}$ これらの結果は, AGEs は 特定の分子と相互作用し，その結果として当該分子 の作用を変化させる可能性を示唆している.

\section{AGEs と TWEAK の相互作用のメカニズム の解析}

続いて筆者は，AGE-TWEAK 相互作用のメカニ ズムを明らかにすることを目的として，TWEAK の部分欠損体を用いた解析を行った。はじめに, TWEAK の $\mathrm{N}$ 末端側を約 20 アミノ酸残基ずつ段階 的に欠損させた分子を，大腸菌発現系を用いて作製 した（Fig. 3)。これらの分子を用いて AGEs のプ ルダウンアッセイを行ったところ，いずれの欠損体 も全長の TWEAK と同様に AGEs に結合すること が示された. ${ }^{13)} こ の$ 結果は，TWEAK の $\mathrm{N}$ 末端側 の領域は AGEs との相互作用に関与しないことを

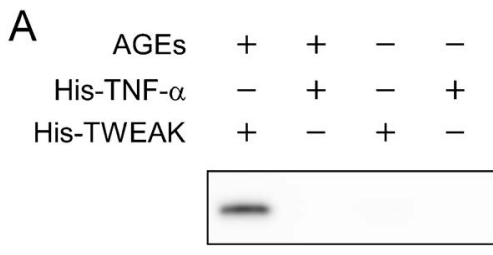

B

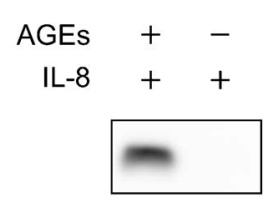

Fig. 2. Interaction between TNF- $\alpha$, TWEAK, IL-8, and AGEs

Anti-AGEs antibody immobilized on beads was incubated with AGEs followed by His-tagged TNF- $\alpha$ ( $25 \mathrm{ng} / \mu \mathrm{L}$, His-TNF- $\alpha)$, His-tagged TWEAK $(25 \mathrm{ng} / \mu \mathrm{L}$, His-TWEAK), or IL- $8(10 \mathrm{ng} / \mu \mathrm{L})$. Molecules bound to beads were analyzed by Western blotting using anti-His-tag antibody (A) or anti-IL-8 antibody (B), respectively. Reproduced from Mol. Cell. Biochem., 434 (1-2), 153-162 (2017), with permission.

示唆している．続いて， $\mathrm{N}$ 末端側と同様に， $\mathrm{C}$ 末端 側を段階的に欠損させた分子を作製し，プルダウン アッセイに供した（Fig. 3)。その結果，TWEAK の全長の約半分まで $\mathrm{C}$ 末端側領域を欠損させた分 子（ $\Delta \mathrm{C} 1-4)$ が, AGEs と結合しないことが示され た。これに対して， $\Delta \mathrm{C} 1-4$ よりも $\mathrm{C}$ 末端側のアミ 


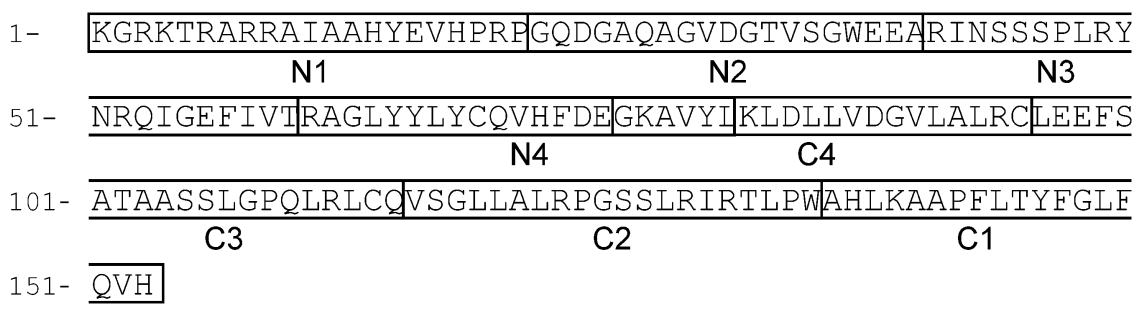

Fig. 3. Primary Structure of TWEAK and Deleted Regions in the AGE-TWEAK Interaction Experiment $\mathrm{N} 1-\mathrm{N} 4$, deleted regions located on the $\mathrm{N}$-terminus side; $\mathrm{C1}^{-} \mathrm{C} 4$, deleted regions located on the $\mathrm{C}$-terminus side.

ノ酸残基が残存している分子 $(\Delta \mathrm{C} 1, \Delta \mathrm{C} 1-2, \Delta \mathrm{C} 1-$ 3）は，TWEAK 全長とほぼ同等に AGEs と結合す

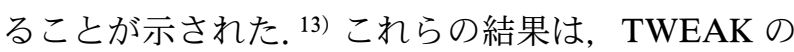
C4 領域が AGEs との相互作用に必要な領域である ことを示唆していると考えられた。 そこで，この C4 領域のみを欠損させた分子（ $\Delta \mathrm{C} 4)$ を作製し， プルダウンアッセイに供した。 その結果，予想に反 して， $\Delta \mathrm{C} 4$ は TWEAK 全長と同等に AGEs と結合 することが示された. ${ }^{13)} こ の$ 結果は, $\mathrm{C} 4$ 領域のみ ならず C 末端側の領域全体が AGE-TWEAK 相互 作用に寄与することを示唆していると考えられた.

そこでさらに，C 末端側に設定した 4 つの領域 （C1-C4）の複数箇所を同時に欠損させた分子を作 製し，同様の検討を行った。 その結果，C3 領域を 除く $\mathrm{C}$ 末端側の 2 力所以上を欠損させた分子が, $\Delta \mathrm{C} 1-4$ と同等に AGEs との結合能を衰失すること が見い出された. ${ }^{13)}$ 以上より, TWEAK の C 末端 領域の大部分が AGEs との相互作用に関与してい ることが強く示唆された.

TWEAK の立体構造は既に明らかとなっており, $2 つ の \beta$ シートがジスルフィド結合により連結され た構造を有する (Fig. 4). ${ }^{14)}$ また，この分子は他の $\mathrm{TNF}$ スーパーファミリー分子と同様に， 3 量体と して作用することが示唆されている. これらの知見 と, 本研究により得られた知見をあわせて考えると,

AGE-TWEAK 相互作用と，AGEsによる TWEAK の作用阻害の関係について以下の可能性が考えられ る.まず，AGEs と相互作用することが示唆された TWEAK の C 末端側領域の一部 (C1, C2 領域) は, TWEAK が 3 量体を形成する際に内側となり, 直 接 3 量体形成に必要となる領域である（Fig. 4). このことから, この領域において AGEs が TWEAK に結合することは， 3 量体化の阻害を介し て TWEAK の作用の抑制に寄与する可能性が考え

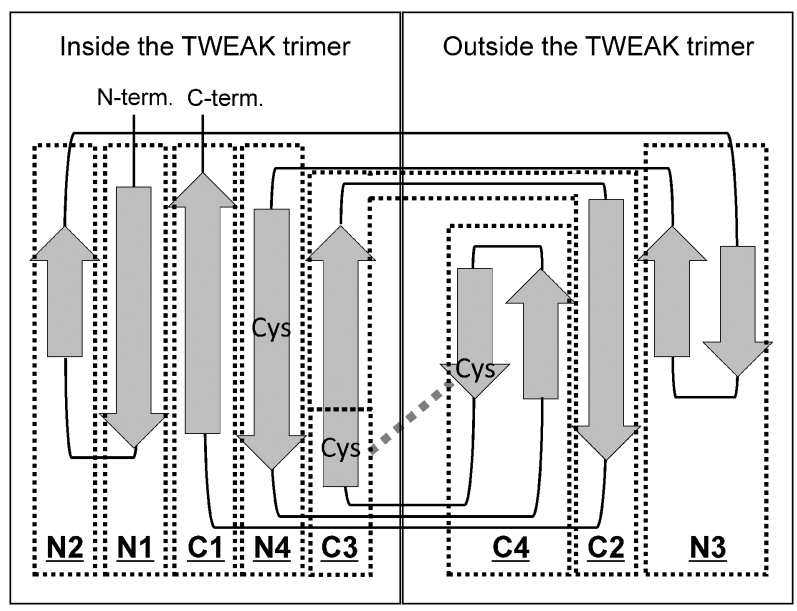

Fig. 4. Schematic Diagram of TWEAK Conformation and Deleted Regions in the AGE-TWEAK Interaction Experiment

Arrow, $\beta$-chain; $\mathrm{N}$-term., $\mathrm{N}$-terminus; $\mathrm{C}$-term., $\mathrm{C}$-terminus.

られる。 さらに，AGE-TWEAK 相互作用により， TWEAK の受容体である Fn-14 との相互作用に必 要な領域が遮蔽され，TWEAK の作用の抑制に寄 与する可能性が考えられる.

以上の結果より，AGEs は TWEAK を捕捉し， その機能を阻害する作用を有すると考えられた。こ の現象は, 生体内におけるAGEs の存在が, TWEAK の TNF- $\alpha$ が刺激する炎症反応を制御する 機能を阻害することにより, 炎症の増悪化や慢性化 に寄与している可能性を示唆している（Fig. 5).

さらに TWEAK は, 複数の疾患への関与が示唆さ

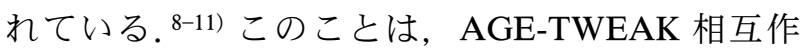
用が，疾患の病態形成に寄与している可能性を示唆 している.

\section{4. おわりに}

AGEs と TWEAK の相互作用のメカニズムの解 析を行った動機の 1 つとして，TWEAK において 見い出した AGEs によるサイトカイン捕捉の対象 

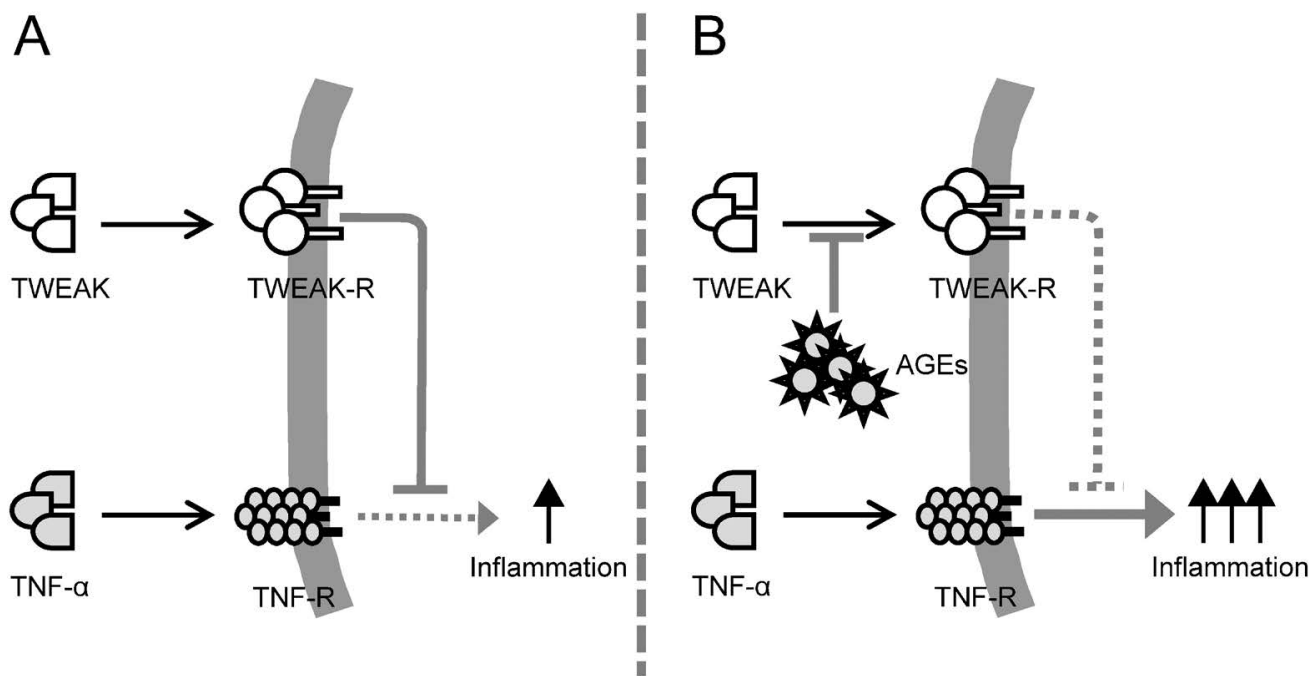

Fig. 5. Schematic Diagram of the Influence of AGEs on the Action of TWEAK

A: TWEAK inhibits TNF- $\alpha$-induced inflammatory reactions. B: TNF- $\alpha$-induced inflammatory reactions are accelerated as a result of the inhibitory action of AGEs on TWEAK. TWEAK-R, TWEAK receptor; TNF-R, TNF receptor.

となるサイトカイン類を探索するための手がかりを 得たいという考えがあった。 TWEAKや IL-8 と AGEs の相互作用メカニズムを明らかにすることに よって，AGEs と結合するモチーフ配列を見い出す ことができれば，データベース検索によって AGEs によるサイトカイン捕捉機構の対象となる分子を網 羅的に同定できる可能性がある。しかしながら,

AGEs と TWEAK の相互作用のメカニズムの解析 により，TWEAK は比較的大きな領域において AGEs と相互作用することが示唆された.この原因 として, AGEs は多様な構造を持った分子の集合体 であることが考えられる。このため，当初に考えた ようにタンパク質の一次構造のみを対象として AGEs 結合モチーフ配列を見い出すことは困難であ ると考えられた.

そこで，約 500 のサイトカイン類を搭載したプロ テインアレイを用いて，AGEs と相互作用する分子 の網羅的探索を試みた。 BSA と，AGEs化した BSA を蛍光標識したプローブを調製し，それぞれ を別のアレイと反応し，蛍光スキャナを用いて検出 した。その結果，約 80 のサイトカイン類が BSA よりも AGEs 化した BSA と強く結合することが示 された。これらの分子には，既に AGEs と相互作 用することを見い出している TWEAK と IL-8 が含 まれていた。 さらにこれらの分子には, AGEs と相 互作用しないことを見い出している TNF- $\alpha$ が含ま れないことが確認された。これらの結果から，この
プロテインアレイ解析により見い出された分子は, 実際にAGEs と相互作用する可能性が高いと考え られた。

現在，この解析により見い出された分子と AGEs の相互作用が当該分子の作用に与える影響の解析を 進めている。これらのうち, ある炎症誘導性サイト カイン類は, TWEAK の場合とは逆に, AGEsの共 存によりその作用が増強されることを見い出してい る。この結果は, AGEs によるサイトカイン捕捉 は，そのサイトカインの作用の阻害に寄与する場合 と，促進に寄与する場合が存在することを示唆して いる.さらに，AGEs と相互作用する可能性が新た に示唆された分子には，炎症反応と直接関係しない 分子が含まれていた。このことは，AGEsによるサ イトカイン捕捉は, 炎症以外の領域においても生理 機能の変化や，それに伴う疾患に関与している可能 性を強く示唆していると考えられる。 今後, これら の分子と AGEs の相互作用により生じる現象につ いても，解析を進めていく予定である.

最近になって，国内メーカーから体内の AGEs 蓄積量を非侵襲で測定する機器が発売された。ま た, 海外メーカー製の類似する機器は，以前から市 販されてきた。これらの機器は，ドラッグストアや 調剂薬局などの店頭において血圧測定器などと並ん で利用できるようになっており，実際に多くの方が 興味深そうな様子で測定を行っている様子を目にす ることが増えてきた。このことは，AGEsが広く一 
般に認識されるようになってきていることを示唆し ていると考えられる，その一方で，AGEsが生体内 でどのように作用しているのかについては，いまだ 不明確な点が多い状態である。

一例として，AGEs の受容体として機能する分子 はRAGE のみであるのかという疑問が挙げられる.

RAGE は，はじめに AGEs と相互作用する分子と して同定され，AGEsの受容体としては最も解析が 進んでいる分子である。一方で，RAGE 以外の分 子が AGEs の受容体として機能する可能性が複数 報告されている，実際に筆者は，RAGE 以外の受 容体が AGEs に起因する炎症反応の誘導に寄与し ている可能性を報告している．免疫担当細胞のモデ ルとして汎用されている RAW264.7 細胞において ゲノム編集により RAGE などの受容体欠損細胞を 作製し，AGEs 刺激に対する反応性の変化を検討し た。その結果，少なくともこの細胞における AGEs への応答には, RAGEよりも Toll-like receptors （TLRs）が大きく寄与していることを見い出した. さらに，これらの受容体刺激によって細胞内で生じ るシグナル伝達系の変化についても知見を得ること ができた. ${ }^{15)}$

このように，現時点で AGEs が生体に影響を与 えるメカニズムは完全に解明されていない，冒頭で 述べたように，これまでに AGEs の作用メカニズ ムとして，(1)生体分子が AGEs 化されることによ る分子の機能変化，及び (2) AGEs 化された分子が RAGE などの受容体を刺激することにより生じる 細胞機能の変化が知られている．筆者の見い出した AGEs によるサイトカイン捕捉は，これらの $2 つ の$ メカニズムに続く，AGEs の新規作用メカニズムで あると考えている.さらに，これまでに認識されて いたメカニズムは，特定の生体分子 (1)，若しく は特定の受容体が存在する細胞（2)）のみにおいて 生じる現象と考えられる。これらに対してサイトカ イン捕捉は，サイトカイン類が機能するすべての領 域において生じる可能性のある現象である。このこ とは，AGEsがこれまで想定されていたよりも，よ り幅広い生理現象に干渉している可能性を示唆して いる。 したがって，AGEsによるサイトカイン捕捉 の解析を進めていくことで，これまで発症要因が不 明であった疾患の発症メカニズムの解明や，新規治 療法の開発に寄与できる可能性がある。今後も引き
続き, AGEs によるサイトカイン捕捉機構のメカニ ズム解明と，その病態生理学的な意義の解明に向け た解析を進めていきたいと考えている.

謝辞本研究を実施するにあたりご指導を賜り ました，就実大学薬学部 森 秀治教授・豊村隆男 講師に深く感謝いたします。また，本研究は就実大 学薬学部生体情報学研究室において遂行されたもの であり，ご協力頂きました共同研究者・研究室学生 の皆様に心より感謝いたします。また，本研究は， JSPS 科研費 $(15 \mathrm{H} 06785,18 \mathrm{~K} 14969)$ ，公益財団法 人ウエスコ学術振興財団, 公益財団法人岡山医学振 興会，公益財団法人両備檉園記念財団のご支援によ り行われたものであり，ここに御礼申し上げます。

利益相反＼cjkstart開示すべき利益相反はない.

\section{REFERENCES}

1) Monnier V. M., Cerami A., Science, 211, 491493 (1981).

2) Henning C., Smuda M., Girndt M., Ulrich C., Glomb M. A., J. Biol. Chem., 286, 4435044356 (2011).

3) Saito M., Marumo K., Osteoporos. Int., 21, 195-214 (2010).

4) Kaji Y., Usui T., Oshika T., Matsubara M., Yamashita H., Araie M., Murata T., Ishibashi T., Nagai R., Horiuchi S., Amano S., Invest. Ophthalmol. Vis. Sci., 41, 362-368 (2000).

5) Mori S., Watanabe M., Toyomura T., Shujitsu Univ. J. Pharm. Sci., 3, 9-15 (2016) .

6) Xie J., Méndez J. D., Méndez-Valenzuela V., Aguilar-Hernández M. M., Cell Signal., 25, 2185-2197 (2013).

7) Wiley S. R., Winkles J. A., Cytokine Growth Factor Rev., 14, 241-249 (2003).

8) Blanco-Colio L. M., Martín-Ventura J. L., Muñóz-García B., Orbe J., Páramo J. A., Michel J.-B., Ortiz A., Meilhac O., Egido J., Arterioscler. Thromb. Vasc. Biol., 27, 916922 (2007).

9) Simón-Muela I., Llauradó G., Chacón M. R., Olona M., Näf S., Maymó-Masip E., Gil P., de la Flor M., Gonzalez Clemente J. M., Vendrell J., Megía A., Eur. J. Clin. Invest., 45, 27-35 (2015) 
10) Ptaszynska-Kopczynska K., MarcinkiewiczSiemion M., Lisowska A., Waszkiewicz E., Witkowski M., Jasiewicz M., Miklasz P., Jakim P., Galar B., Musial W. J., Kaminski K. A., Cytokine, 80, 7-12 (2016) .

11) Bertin D., Stephan D., Khrestchatisky M., Desplat-Jégo S., Front. Immunol., 4, 489 (2013).

12) Watanabe M., Toyomura T., Wake H., Liu K., Teshigawara K., Takahashi H., Nishibori M., Mori S., Mol. Cell. Biochem., 434, 153162 (2017).
13) Watanabe M., Toyomura T., Wake H., Liu K., Teshigawara K., Takahashi H., Nishibori M., Mori S., Biotechnol. Appl. Biochem., 66, 254-260 (2019).

14) Lammens A., Baehner M., Kohnert U., Niewoehner J., von Proff L., Schraeml M., Lammens K., Hopfner K.-P., PLoS One, 8, e62697 (2013).

15) Watanabe M., Toyomura T., Wake H., Liu K., Teshigawara K., Takahashi H., Nishibori M., Mori S., Biotechnol. Appl. Biochem., 67, 265-272 (2020). 